\title{
Benzylation of Phenol with Benzyl Alcohol in the Presence of Sulphuric Acid
}

\author{
Mahmud Hasan Tareque, Mohammad Ismail, Prashanta Chakravarty, \\ Ashequl Alam Rana and Manoranjan Saha \\ Department of Applied Chemistry and Chemical Technology \\ University of Dhaka, Dhaka-1000, Bangladesh
}

\begin{abstract}
Benzylphenol has been produced in high yield by the benzylation of phenol with benzyl alcohol in the presence of sulphuric acid. The effect of variation of temperature, molar ratio of phenol to benzyl alcohol, time of reaction, concentration and amount of sulphuric acid have been studied on the reaction.
\end{abstract}

\section{Introduction}

The excellent antioxidants and multifunctional stabilizers in fuels, lubricating oils and wide variety of oxygen sensitive materials are based on alkylphenols. ${ }^{1-4}$ Moreover some of their derivatives are strong herbicides, bactericides and insecticides. ${ }^{3,7}$ They are pour point depressants for transmission fluids, corrosion inhibitors and plasticizers for polymers. ${ }^{8-10}$ They are also used in paint and varnishes, dye, perfume, adhesive and soap industries. , $^{311-12}$ Alkylphenols with an alkyl group of 5-8 carbon atoms are strong bactericides and with an alkyl group of 9-12 carbon atoms are valuable intermediates for nonionic detergents. ${ }^{2,3,13,14}$ Phenol has been alkylated by different alcohols by several authors. ${ }^{15-21}$ But studies on benzylation of phenol are rare. Only report available deals with the benzylation of phenol with benzyl alcohol in presence of $\gamma-\mathrm{Al}_{2} \mathrm{O}_{3}$ as catalyst. ${ }^{4}$ Sulphuric acid is the most effective and inexpensive catalyst for the phenol alkylation process. This could be one of the most suitable catalyst for the benzylation of phenol.

In the present work the reaction of phenol with benzyl alcohol in the presence of sulphuric acid has been investigated.

\section{Materials and Methods}

The reactions were carried out in a three necked round bottomed flask fitted with a condenser, a thermometer, a dropping funnel and a magnetic stirrer. Phenol and sulphuric acid were charged into the flask and heated to the desired temperature and benzyl alcohol was introduced into the mixture gradually for a certain period of time (time of addition) 
with constant stirring. The reaction mixture was stirred for another period of time (time of stirring) at the same temperature after the complete addition of total amount of benzyl alcohol. The reaction mass was then cooled to room temperature, dissolved in petroleum ether, neutralized, washed with distilled water several times and subjected to distillation. Unreacted reactants and solvent were distilled off at atmospheric pressure. The residual product was finally distilled and characterized by spectral means.

\section{Results and Discussion}

Reaction of phenol with benzyl alcohol has been studied in the presence of sulphuric acid over the temperature range of 100 to $140^{\circ} \mathrm{C}$. The reaction gave benzylphenol. The effects of variation of different parameters on the yield of the product have been shown in the Tables I-V.

Table I. The effect of variation of temperature on the reaction of phenol with benzyl alcohol in presence of sulphuric acid

\begin{tabular}{c|c}
\hline Temperature, ${ }^{\mathrm{O}} \mathrm{C}$ & \% Yield of benzylphenol \\
\hline 100 & 27.8 \\
120 & 64.9 \\
140 & 70.2 \\
160 & 72.5 \\
\hline
\end{tabular}

(molar ratio of phenol to benzyl alcohol $=4: 1$, time of addition $=2 \mathrm{~h}$, time of stirring $=1 \mathrm{~h}$ and amount of $94 \%$ sulphuric acid $=5 \%$ by wt. of phenol)
The yield of the product increased with the increase in temperature. Thus the yield increased from 27.8 to $70.2 \%$ on increasing the temperature from 100 to $160^{\circ} \mathrm{C}$ (Table I)

The yield of the product increased also with the increase in molar ratio of phenol to benzyl alcohol. Thus the yield increased from 70.2 to $87.4 \%$ when the molar ratio of phenol to benzyl alcohol was increased from 4:1 to 8:1 (Table II).

Table II. The effect of variation of molar ratio of phenol to benzyl alcohol reaction of phenol with benzyl alcohol in presence of sulphuric acid

\begin{tabular}{c|c}
\hline $\begin{array}{c}\text { Molar ratio of phenol } \\
\text { to benzyl alcohol }\end{array}$ & \% Yield of benzylphenol \\
\hline $4: 1$ & 70.2 \\
$5: 1$ & 79.4 \\
$6: 1$ & 84.9 \\
$8: 1$ & 87.4 \\
\hline
\end{tabular}

(temperature $=140^{\circ} \mathrm{C}$ time of addition $=2 \mathrm{~h}$, time of stirring $=1 \mathrm{~h}$ and amount of $94 \%$ sulphuric acid $=5 \%$ by wt. of phenol)

The yield of the product increased also with the increase in the concentration of sulphuric acid. The yield increased from 73.8 to $84.9 \%$ when concentration of sulphuric acid was increased from 70 to $94 \%$ (Table III)

The yield of the product was found to increase with the increase in the amount of sulphuric acid. The yield increased from 70.5 
Table III. The effect of variation of concentration of sulphuric acid on the on the reaction of phenol with benzyl alcohol

\begin{tabular}{c|c}
\hline $\begin{array}{c}\text { Concentration of } \\
\text { sulphuric acid, \% }\end{array}$ & \% Yield of benzylphenol \\
\hline 70 & 73.8 \\
80 & 80.0 \\
94 & 84.9 \\
\hline
\end{tabular}

(molar ratio of phenol to benzyl alcohol $=6: 1$, temperature $=140^{\circ} \mathrm{C}$ and amount of sulphuric acid based on $94 \%$ acid $=5 \%$ by wt. of phenol)

to $85.8 \%$ when the amount of sulphuric acid was increased from 2 to $8 \%$ (Table IV).

The effect of the variation of time of reaction on the yield of the product has been shown in Table V. The yield of the product increased
Table IV. The effect of variation of the amount of sulphuric acid on the reaction of phenol with benzyl alcohol

\begin{tabular}{c|c}
\hline $\begin{array}{c}\text { Amount of 94 \% sulphuric acid, } \\
\text { \% by wt of phenol }\end{array}$ & $\begin{array}{c}\text { \% Yield of } \\
\text { benzylphenol }\end{array}$ \\
\hline 2 & 70.5 \\
5 & 84.9 \\
8 & 85.8 \\
\hline
\end{tabular}

(temperature $=140^{\circ} \mathrm{C}$, molar ratio of phenol to benzyl alcohol $=6: 1$, time of addition $=2 \mathrm{~h}$ and time of stirring $=1 \mathrm{~h}$ )

with the increase in the time of addition. By increasing the time of addition to a value greater than $2 \mathrm{~h}$, no significant effect on the yield was observed. The yield also increased by additional stirring. The best yield was obtained when the time of stirring was $3 \mathrm{~h}$.

Table $V$. The effect of variation of time of reaction on the reaction of phenol with benzyl alcohol

\begin{tabular}{c|c|c|c|c}
\hline Set No. & Time of addition, $\mathrm{h}$ & Time of stirring, $\mathrm{h}$ & Total time of reaction, $\mathrm{h}$ & \% Yield of benzylphenol \\
\hline \multirow{3}{*}{1} & 1 & 0 & 1 & 72.0 \\
& 2 & 0 & 2 & 80.9 \\
& 3 & 0 & 3 & 90.3 \\
2 & 1 & 3 & 4 & 92.8 \\
& 2 & 2 & 4 & 95.0 \\
& 3 & 1 & 4 & 94.5 \\
3 & 2 & 0 & 2 & 80.9 \\
& 2 & 1 & 3 & 84.9 \\
& 2 & 2 & 4 & 95.0 \\
\hline
\end{tabular}

(temperature $=140^{\circ} \mathrm{C}$, molar ratio of phenol to benzyl alcohol $=6: 1$, concentration of sulphuric acid $=94 \%$ and amount of $94 \%$ sulphuric acid $=5 \%$ by wt. of phenol) 
Table VI. The ${ }^{1} \mathrm{H}$ NMR spectrum of benzylphenol

\begin{tabular}{l|c}
\hline \multicolumn{1}{c|}{$\begin{array}{c}\text { Observed signals } \\
\text { of the protons }\end{array}$} & $\begin{array}{c}\text { Chemical shift } \\
\text { in } \delta \text { ppm }\end{array}$ \\
\hline $\begin{array}{l}\text { Two protons of }-\mathrm{CH}_{2}-\text { on } \\
\text { benzyl group }\end{array}$ & $3.7-3.9$ \\
One proton on the -OH group & 5.4 \\
All aromatic ring protons & $6.4-7.1$ \\
\hline
\end{tabular}

Thus the maximum yield of benzylphenol was obtained under the following conditions: temperature $=140^{\circ} \mathrm{C}$, molar ratio of phenol to benzylphenol $=6: 1$, concentration of sulphuric acid $=94 \%$, amount of sulphuric acid $=5 \%$ by wt. of phenol, time of addition $=2$ $\mathrm{h}$ and time of stirring $=3 \mathrm{~h}$.

The UV spectrum of the product showed strong absorption at $\boldsymbol{\lambda}_{\max }=\mathbf{2 8 6 . 0} \mathbf{n m}$ in $0.01 \mathrm{M}$ methanol solution.

In the IR spectrum of benzylphenol, absorption bands at $750 \mathbf{~ c m}^{-1}$ and $850 \mathbf{~ c m}^{-1}$ accounted for $o$ - disubstituted and $p$ - disubstituted benzene ring, respectively. Bands at $\mathbf{3 0 2 5}$ $\mathbf{c m}^{-1}, 2900 \mathbf{c m}^{1}$, and $1595 \mathbf{c m}^{-1}$ accounted for aromatic $=\mathrm{C}-\mathrm{H}$, saturated $\mathrm{C}-\mathrm{H}$ and benzene

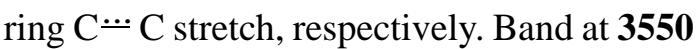
$\mathbf{c m}^{-1}$ showed the presence of -OH group in the product.

\section{References}

1. A. M. Ravikovich. Antioxidants for minerals and synthetic lubricating oils. Chemistry and technology for fuels and oils. 11 (1964) 64-71.
2. R. N. Shreve and J. A. Brink. Chemical Process Industries. 4th Ed. (1977) 814.

3. N. N. Lebedev. Chemistry and technology of basic organic and petrochemical synthesis, Mir. Publishers, Moscow, Vol. 1 and 2 (1984) 638.

4. A. H. Fildey, H. G. Braxton and R. B. Maltsner. U. S. 4514577 (Cl. 588-744; CO7C39/14). Chem. Abstr. (1985). 103, 37198s.

5. S. S Nemetkin, Y. A. Baskahov and N. N. Melnikov. Zh. Obsh. Khim. 12 (1951) 21462150.

6. N. N. Melnikov, Y. A. Baskahov and K. S. Bokrev. Gkhi. Moscow. (1954) 38.

7. P. S. Belov and V. I. Isagulyants. Zh. Prikl. Khim. 37(11) (1964) 2505-2508.

8. V. D. Egorov, A. I. Prokazov, A. G. Rumyantsev, L. A. Podlesnaya, G. A. Tarakanov, V. F. Zhelobad'Ko, L. D. Melnikoova and V. G. Grigoryan. Neftepererab. Neftekhim. Moscow. 12 (1978) 31-32.

9. E. M. Nilikova, R. E. Spivok and A. A. Bakhshi-Zade. Azerb. Neft. Khoz. 54(10) (1974) 41-44.

10. A. J. George and R. H. Adahms. US. Patent. (1972) 3691121.

11. L. A. Kheifits and A. S. Podberiwina. Tr. Veses. Nauch-Issled. Inst. Sir Natur. Dushistykh Veshehestv. 8 (1968) 115-142. 
12. P. S. Belov. Bases of technology of petrochemical synthesis. Khimiya, Moscow, (1982) 638.

13. S. A. Dimitriev, K. D. Korener and O. N. Tsvetkov. Torfyanaya. Prom. 32(6) (1961) 24-27.

14. M. A. Ashimov, M. A. Muralova and Z. A. Dadasheva. Vop. Neftekhim. No. 3 (1971) 110-113

15. I. Romadane and G. Stiporicks. Polilekhn. Inst. Fok. 2(7) (1959) 43-47

16. I. Romadane, and A. Lismane. Uch. Inst. Khim. Fok. 6(8) (1962) 133.

17. C. Quasim, H.R. Sonawane, M.S. Wadia and N. I. Dufta. Indian, Chem. 9(2) (1971) 181-182.
18. S. A. Sarankina, A. B. Kuchkarov, F. K. Kurbanov, and B. V. Rakhimova. Izv. Zaved. Khim. Tekhnol. 18(5) (1975) 743-744.

19. I. Morgos, P. Sallay, L. Forkas, I. Ruszmak. and B. Bartha. Kolor, Krt. (Hung), 26(3-4) (1984) 131-142.

20. V. N. Zhdmarova, S. V. Rudenko, O. K. Smirnov, S. G. Potapenko, S. M. Levi and A. D. Kopeina. Tezisy Doki. Simp. Sint. Primer. Poverkhn.-Akt. Vvestichestv PromSti. Konofotomater. (1977) 20-21.

21. V. A. Kombulova. Zh. Prikl. Khim. 38(12) (1965) 2871-2872. 
Ahmed, Haque, Hossain, Rahman, Alamgir and Jalal 
